\title{
THE TRENDS OF THE CHANGES OF STRATEGIC COMMUNICATIONS WITHIN THE PUBLIC ADMINISTRATION OF UKRAINE (2014-2021)
}

\author{
Borovskiy O. O., Tkachenko O. O.
}

\section{INTRODUCTION}

It is obviously that it is important for existence of every state to be long-term and efficient. So, it is important for every state, its rulers and people to orient state, its functioning and profits for them from it to longterm. Such long-term strategic orientation of a state for its efficiency assumes that every management of state meaning public administration must be also strategic for its effectiveness. So, the actions of the state in every sphere including the informational, organization of its public administration, interaction of its actors and the state's response to external threats must be strategic, too. This base for position that commutations within public administration must be also strategic. Especially, the necessity of such strategic organization of state, its public administration and communication within it becomes obvious facing these threats and challenges for them. A strategically oriented state is prepared for solving problems rapidly or in a protracted way in case the search of rapid solutions is failed. However, a short-term oriented state is not ready for both variants, it takes great loss or even crashes facing problems. The frequency of facing informational and communicational challenges has increased in our information age, so the importance of the strategic organization of the communication within public communications has increased, too. The effectiveness of Ukrainian state has been low over 30 years of its existence. And the Ukrainian state has faced the greatest challenge to its existence, namely the hybrid war that Russian Federation wages against the existence of Ukraine at whole. This war causes many problems for Ukraine, as well as problems within the informational sphere. Thus, organizing and improving strategic communications within the public administration of Ukraine for the subject of this administration, other Ukrainian people and Ukraine in general are greatly relevant.

And the authors are aimed at researching the changes of strategic communications within the public administration of Ukraine having been since 2014. 


\section{Prerequisites of the changes' necessity of strategic communications within public administration of Ukraine}

The relevance of the necessity for the changes of the strategic communications within public administration of Ukraine is obvious according to the analysis of the main challenges to their existence since 2014 and the necessity for these challenges to be overwhelmed. Hybrid war is the key component of the main challenge of these ones and this is the reason for the current aggression of the Russian Federation against Ukraine. This war is hybrid because it has not been proclaimed and is waged by non-direct, hybrid methods. What is the essence of the hybrid war and what should be an effective response to it? As the Ukrainian specialist in this sphere Magda Y. describes this phenomenon: "Hybrid war is not an invention of nowadays. Combinations of informational, psychological, economic and military confrontation have been used in the past. But the hybridity of the modern conflict is that the distribution of these factors is fundamentally different. The use of means and features of the information society is much more powerful" ${ }^{1}$.

It is necessary to build strong information and communication systems for an attacked state to defend itself from such assault and to counterattack while the attacking state makes extensive use of informational subversion, propaganda and misinformation about the state and its subordinate population, and the material base of these means cannot be physically eliminated, as direct war is not declared. The relevance of such themes has been marked in Ukraine since 2014. It is emphasized in the works of numerous researchers in the field, such as Magda Y. and Ruban $\mathrm{Y}^{2}$. It is stated by the Ukrainian authorities in legislative acts, for example, by the National Security and Defense Council of Ukraine (NSDC) in the Decision "About the Doctrine of Information Security of Ukraine" from 29th of December, 2016 year enacted by Presidential Decree № 47/2017 from 25th of February, 2017 year: "The use of hybrid warfare technologies against Ukraine by the Russian Federation has turned the information sphere into a key arena of confrontation. Russian Federation uses the latest information technologies exactly against Ukraine to influence the minds of citizens, to incite national and religious hatred, to make propaganda of aggressive war, change of constitutional order by force and violation of Ukraine's

${ }^{1}$ Магда Є.В. Виклики гібридної війни інформаційний вимір. Наукові записки Інституту законодавства Верховної Ради України. 2014. № 5. С. 142

2 Рубан Ю.Г. Стратегія гуманітарної безпеки України у контексті гібридної війни. URL: http://www.historians.in.ua/index.php/en/dyskusiya/1341-yurii-rubanstratehiia-humanitarnoi-bezpeky-ukrainy-u-konteksti-hibrydnoi-viiny (дата звернення 16.04.2021) 
sovereignty and territorial integrity" ${ }^{3}$. International partners of Ukraine have also emphasized this, providing valuable advice for our country in the sphere based on the experience of their own countries' reactions to such threats. For example, it has been done by General Philip Breedlove Supreme Allied Commander Europe (NATO) in 2013-2016.

The informational sphere of Ukraine has been full of references to hybrid war and related terminology by present. It is also demonstrated by the authors' research of the content of the all-Ukrainian publication "Day", there are many materials related to hybrid war. The research is conducted with the content-analyze method in order to determine quantitative parameters of the use of concepts related to hybrid war. These are "information policy", "information security" and typical communicative relations to the words "information" and "security". The results of this research are detailed below.

Table 1

Typical communicative relations to the word "informational" within the content of the "Day" (2018-2019)

\begin{tabular}{|c|c|}
\hline \multirow{20}{*}{$\begin{array}{l}\text { "Informacijny'j (-a, -e, -i)" } \\
\text { (informational) }\end{array}$} & "polity'ka" (policy) \\
\hline & "bezpeka" (security) \\
\hline & "robota" (work) \\
\hline & “zagroza" (threaten) \\
\hline & "pry'vid" (cause) \\
\hline & "suspil'stvo" (society) \\
\hline & "pole" (field) \\
\hline & "agresiya" (aggression) \\
\hline & "procesy" (processes) \\
\hline & "arena" (arena) \\
\hline & "prostir" (sphere) \\
\hline & "vijna" (war) \\
\hline & “sproty’v" (resistance) \\
\hline & "ilyuziya" (illusion) \\
\hline & "vijs'ko" (army) \\
\hline & "obsluga" (service) \\
\hline & "sfera" (sphere) \\
\hline & "podiya" (event) \\
\hline & "insty'tuciya" (institution) \\
\hline & "shum" (noise) \\
\hline
\end{tabular}

3 Указ Президента України № № 47/2017: Указ Президента України від 25 лютого 2017 року. URL: https://zakon.rada.gov.ua/laws/show/47/2017\#Text (дата звернення 15.04.2021)

Vandiver J. SACEUR: Allies must prepare for Russia 'hybrid war'. URL: http://www.stripes.com/news/saceur-allies-must-prepare-for-russia-hybrid-war1.301464 (access date 16.04.2021) 


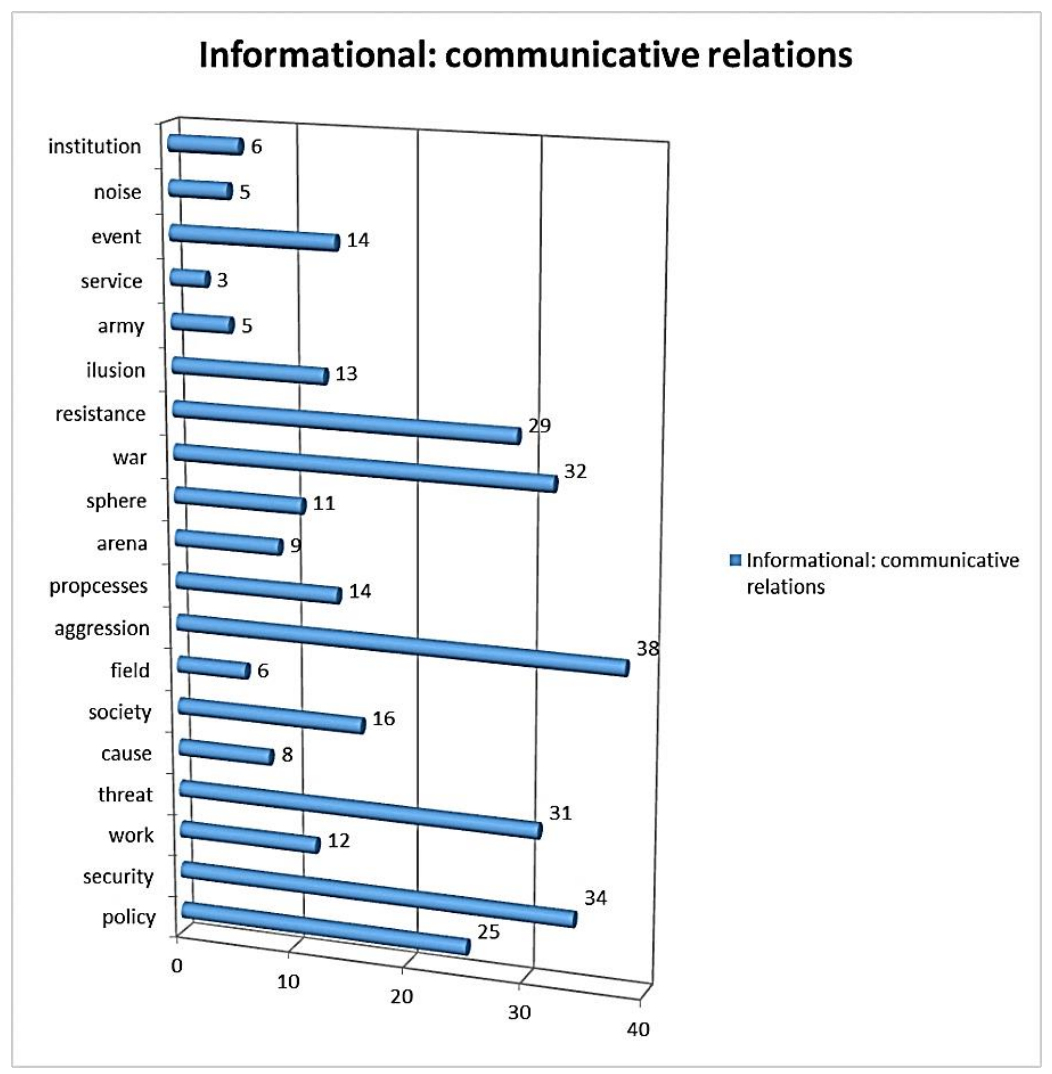

Fig. 1. Quantitative parameters of using communicative relations to the word "informational" within the content of the "Day" (2018-2019)

The greatest connections of the word "informational" may be traced in the following options: informational aggression (That will be according to the definition of military aggression from United Nations General Assembly Resolution 3314 of 1974, if projection of this concept to the information sphere will be made: "use of informational force by a State against the sovereignty, territorial integrity or political independence of another State" ", informational security (according to article 1 of the Law of Ukraine "About the Telecommunications", if the projection of this concept is not only to information security of

5 Definition of Aggression, United Nations General Assembly Resolution 3314 (XXIX). URL: http://hrlibrary.umn.edu/instree/GAres3314.html (access date 16.04.2021) 
telecommunications networks, but also in general: "the ability of information networks to protect against destruction, distortion, blocking, unauthorized leakage or from the violation of the established order of its routing" ${ }^{\prime 6}$, information war (according to the Ukrainian researcher of this sphere Shpyga P.: "a set of political, legal, socio-economic, psychological actions for the capture of information space, displacement of the enemy from the information sphere, the destruction of their communications, the deprivation of their means of communication, as well as other similar purposes"7, information policy (according to Article 3 of the Law of Ukraine "About the Information" it is the policy, that consists of: "providing access to information for everyone, providing equal opportunities for the creation, collection, receipt, storage, use, distribution, protection of information; providing conditions for information society's establishment of the state; providing openness and transparency of the subjects of power; creation of informational systems and networks, developing e-government; constant updating and storing the national information resources; organizing the state information security; promoting international cooperation in the informational sphere and the state's entry to the informational space" ${ }^{8}$.

Collected statistics also validates the importance and relevance of the information sphere of Ukrainian society and threats to it, including such threats from external actors. Security concepts are closely related to this theme. Monitoring the last two years' content of the all-Ukrainian publication "Day" validates the actualization of the concept of "strategic security" for the state.

\footnotetext{
6 Закон «Про телекомунікації»: Закон України від 18 листопада 2003 року. URL: https://zakon.rada.gov.ua/laws/show/1280-15\#Text (дата звернення 17.04.2021)

7 Шпига П.С. Основні технології та закономірності інформаційної війни. Проблеми міжнародних відносин / Шпига П.С., Рудник Р.М. 2014. № 8. С. 328

Закон «Про інформацію»: Закон України від 2 жовтня 1992 року. URL: https://zakon.rada.gov.ua/laws/show/2657-12?find=1\&text=політика\#w1_2 (дата звернення 17.04.2021)
} 
Table 2

Typical communicative relations to the word "security" within in the content of the "Day" (2018-2019)

\begin{tabular}{|l|c|}
\hline \multirow{4}{*}{ "Bezpeka" (security) } & "strategichna" (strategic) \\
\cline { 2 - 2 } & "nacional'na" (national) \\
\cline { 2 - 2 } & "energety'chna" (energetic) \\
\cline { 2 - 2 } & "ekologichna" (ecological) \\
\cline { 2 - 2 } & "publichna" (public) \\
\cline { 2 - 2 } & "suchasna" (modern) \\
\cline { 2 - 2 } & "Chomads'ka" (civil) \\
\cline { 2 - 2 } & $\begin{array}{c}\text { "kiberbezpeka (bezpeka v } \\
\text { kiberprostori)" (cybersecurity or } \\
\text { security in the cyber space) }\end{array}$ \\
\hline & "informacijna" (informational) \\
\hline
\end{tabular}

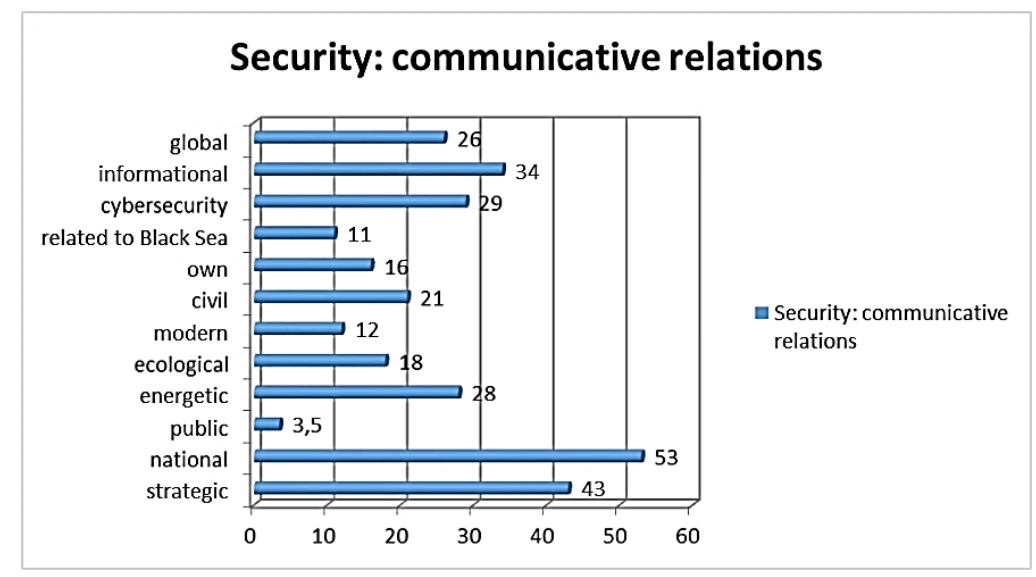

Fig. 2. Quantitative parameters of using of communicative relations to the word "security" within the content of the "Day" (2018-2019)

It is obvious from this content analysis, that the terms "national security", "information security", "global", "strategic security" and "cybersecurity" are used most frequently. This is related to the information challenges and threats posed by Russia in the information space of Ukraine. 


\section{Implemented changes of strategic communications within public administration of Ukraine (2014-2019)}

The reaction of the Ukrainian authorities by Ukrainian society supported to the threats in the information sphere from the external enemy was the establishment of changes in strategic communications. These are changes exactly in strategic communications, because it is the most relevant form of communication to improve the actions of the state in the information space, the organization of public administration, the interaction of its actors and the state's response to external threats. It is important to mention the strategic communication's notion from the sphere of legislative regulation of the USA, because its representatives firstly studied this phenomenon from the position of public interest. It is the notion from "National Strategy for Public Diplomacy and Strategic Communication" enacted on the14th of December 2006 by the special American structure for the establishment of strategic communications, namely the Strategic Communication and Public Diplomacy Policy Coordinating Committee. This is the notion that marks strategic communication as "a coordination of public diplomacy across the interagency community that should always strive to support nation's fundamental values and national security objectives by next steps:

- underscoring national commitment that is freedom, human rights and the dignity and equality of every human being for USA;

- reaching out to those who share our ideals;

- supporting those who struggle for our ideals that are freedom and democracy for USA;

- countering those who espouse contradictory ideologies to these ideals that are ideologies of hate and oppression for USA" $"$.

The phenomenon of strategic communications is relevant for scientific researches. Theoretical and practical aspects of its functioning are researched by many scientists of several sciences, including sociology, political science, linguistics, public administration, social communications, etc. The main features of strategic communications are outlined by the following ways within Ukrainian science. For example, according to the Ukrainian researcher Pelepeichenko L., they "1) nominate only measures of communication aimed at the good of the country at whole or its institutions; 2) are determined by social conditions, current tasks of the state and its institutions; 3) require

9 US National Strategy for Public Diplomacy and Strategic Communication. URL: https://2001-2009.state.gov/documents/organization/87427.pdf (access date 16.04.2021). P. 8, 2. 
justification and the establishment of a clear plan of communicative interaction; 4) provide intergovernmental, interstate, intersectoral cooperation; 5) involve working with different target audiences (groups)" 10 .

Therefore, since the communication plays an important role in statebuilding and the dialogue between the state, its government and civil society, public administration cannot be properly organized without communication, as well as strategic communications, which are one of the most effective tools for promoting their interests.

All of the above about the strategic communications and their relevance for Ukraine since 2014 has been enshrined in Ukrainian legislation. Even the phenomenon of strategic communications was legally defined within the Decision of the NSDC "About the Doctrine of Information Security of Ukraine" as a "coordinated and proper use of communication capabilities of the state that are public diplomacy, public relations, military relations, information and psychological operations, measures aimed at promoting the goals of the state" ${ }^{11}$. The mechanism of the realization of Ukrainian information security in the conditions of hybrid war against the Russian Federation and other increasing threats and changes of Ukrainian strategic communications in this direction have been established in all details. This realization began incessantly after the enactment of this Resolution of the NSDC. This Decision ordered:

1. "The NSDC must coordinate the activities of executive authorities to provide national security in the information sphere in accordance to the Constitution of Ukraine and to procedure established by law.

2. The Cabinet of Ministers of Ukraine must organize the information policy of the state, provide financial resources to the programs related to the information security, guide and coordinate the work of Ministries, other executive bodies in this area.

3. The Ministry of Information Policy of Ukraine in accordance with the established procedure must be entrusted to organize and provide:

- monitoring mass media and public resources of the domestic Internet segment in order to detect information prohibited for distribution in Ukraine;

${ }^{10}$ Пелепейченко Л. М. Стратегічні комунікації силових структур України в сучасному соціальному контексті. Інформаційна безпека людини, суспільства, держави. 2017. № 1 (21). С. 34.

11 Указ Президента України № № 47/2017: Указ Президента України від 25 лютого 2017 року. URL: https://zakon.rada.gov.ua/laws/show/47/2017\#Text (дата звернення 15.04.2021) 
- monitoring threats to national interests and national security in the information sphere;

- assistance for the Ministry of Foreign Affairs of Ukraine in reporting the Ukrainian official position to foreign media;

- establishment of current priorities of state information policy, control of their implementation;

- coordination of the activities of central and local executive authorities in the sphere of providing the Ukrainian information sovereignty;

- government communications;

- crisis communications, especially during the anti-terrorist operation and the special period;

- taking measures in the information sphere for the cases of legal regimes' establishment of state of emergency or martial law;

- elaboration of strategic narrative and its implementation;

- elaboration and implementation of the strategy of information providing of the process of freeing and reintegration of temporarily occupied territories;

4. The Ministry of Foreign Affairs of Ukraine in accordance with the established procedure must be entrusted with:

- formation and implementation of the Strategy of Public and Cultural Diplomacy of Ukraine;

- coordination of information activities of state institutions in the foreign policy sphere;

- providing promotion of the Ukraine's interests abroad by information measures;

- providing to report the Ukrainian official position to the leaders of foreign states, their parliaments and governments, foreign policy departments, business representatives and experts, general public, promoting of the positive image of Ukraine;

- promoting of Ukrainian TV channels into cable and satellite networks abroad;

- establishing cooperation with international partners both bilateral and multilaterally in order to apply international experience and best practices in the context of countering information threats.

5. The Ministry of Defense of Ukraine must provide the functioning of the system of military-civilian relations in the positions of permanent dislocation and deployment of units of the Armed Forces of Ukraine, 
other Ukrainian military formations, as well as it must be entrusted to organize and provide:

- connections with Ukrainian and foreign media on the coverage of the situation in the region of the anti-terrorist operation in the Donetsk and Luhansk oblasts;

- counteracting the special information transactions directed against the Armed Forces of Ukraine and other Ukrainian military formations;

- maintenance with information tools for the implementation of the defense tasks of Ukraine;

- report the credible information to the military personnel of the Armed Forces of Ukraine, other Ukrainian military formations, especially by the media of the Armed Forces of Ukraine.

6. Ministry of Culture of Ukraine, the State Agency of Ukraine for movie, the National Council of Ukraine of Television and Radio Broadcasting, the State Committee for Television and Radio Broadcasting of Ukraine within the limits of their competence must participate in providing the protection of the Ukrainian information space from the audiovisual and printed propaganda production of the aggressor state, establish priorities and incentives for the development of Ukrainian cinema, television content, book printing, especially for coverage of the heroic resistance to the Russian aggression by the Ukrainian people.

7. The Security Service of Ukraine within the limits of its competence must carry out:

- monitoring the domestic and foreign media and the Internet by using special methods of identifying the threats of Ukraine's national security in the information sphere;

- counteraction against special information transactions aimed at undermining the Ukrainian constitutional system, sovereignty and territorial integrity, escalation of socio-political and socio-economic situations.

8. Intelligence services of Ukraine during of intelligence activities must facilitate the establishment and protection of Ukraine's national interests in the information sector abroad, counteract the external threats to the information security of the Ukraine.

9. State Special Communications Service of Ukraine must provide within the limits of competence the formation and implementation of state policy in the areas of special communication, information protection, telecommunications and the use of the radio frequency resource of Ukraine. 
10. The National Institute for Strategic Studies should provide scientific, analytical and expert support of the organization and implementation state information policy" ${ }^{\prime 2}$.

\section{The further necessary changes of strategic communications within public administration of Ukraine (2019-2021)}

The necessity for further changes of strategic communications within public administration of Ukraine is obvious nowadays, especially against the new challenges in the sphere, in spite of considerable measures to change and strengthen strategic communications as a counteraction to the hybrid war that the Russian Federation wages against Ukraine in the informational sphere. It is necessary to distinguish the most necessary further changes in the following directions:

\section{In the sphere of legislative regulation}

Since the beginning of holding the post by the new President of Ukraine Volodymyr Zelenskyy, as the result of the second round of the presidential elections on 21th of April, 2019 and by people's deputies of the Ukrainian parliament, Verkhovna Rada of new IX convening, as the result of the elections of people's deputies on 21th of July, 2019 the legislative regulation of a number of state institutions has been changed fundamentally. And many of these institutions were the system components of the realization of the changes of strategic communications. In particular, Ministry of Information Policy did not exist at all and the Ministry of Culture was acting as Ministry of Culture, Youth and Sports up to the 30th of March, 2020 within both Cabinet of the Ministers (governments) of Ukraine, formed by the Verkhovna Rada of the new convening, headed by Oleksiy Goncharuk and by Denys Shmyhal. Since the 30th of March, 2020, both of these Ministries have been acting in the form of a united Ministry of Culture and the Ministry of Information Policy. However, this subject is not envisaged in the system of the subjects of the implementation of the changes of strategic communications within the public administration of Ukraine by the "Doctrine of Information Security", as well as it is not entrusted with any tasks which must be entrusted to it. However, the realization of the tasks, entrusted to the Ministry of Culture and the Ministry of Information Policy in accordance with the "Doctrine of Information Security" is unnecessary now for any state institution. Therefore, the legislative

12 Указ Президента України № № 47/2017: Указ Президента України від 25 лютого 2017 року. URL: https://zakon.rada.gov.ua/laws/show/47/2017\#Text (дата звернення 15.04.2021) 
incentives for certain realization of these tasks are absent. Then, it is strongly necessary to change the legislative regulation of the "Doctrine of Information Security" by a new NSDC Decision, because any changes in previous acts of this format are impossible. However, it has become a more complex task for legislation due to the fact that President Zelenskyy abolished the "National Security Strategy", introduced on the basis of the Presidential Decree No. 287/2015 dated the 26th of May, $2015^{13}$ by his Decree No. 392/2020 dated the 14th of September, 2020. And the current President of Ukraine enacted the new Decision of the NSDC "About the Strategy of National Security of Ukraine" dated the 14th of September 14, 2020 instead of the previous similar Strategy. The Decision of NSDC dated the 14th of September, 2020 clearly regulates that the new "strategy is the basis for the development of such acts for planning in the spheres of Ukrainian national security and defense, that is to determine the ways and tools for its implementation"14. These are 14 new strategies, including the strategy of information security, that will have to be created precisely taking into account a new "Strategy of National Security of Ukraine". So, the necessary further changes of strategic communications within the public administration of Ukraine in this direction are: the elaboration and implementation of "Strategy of information security of Ukraine" with the redistribution of functions in the system of subjects of implementation of strategic communications' changes in accordance with new institutions of public administration in Ukraine.

\section{In the sphere of implementation in the political practice}

1. It is surely possible to legislatively enshrine such redistribution of functions. However, it is necessary to take into account the new specifics of these subjects in their activity within the political reality. Thus, we have the following tasks of the Ministry of Culture and Information Policy in accordance with the Resolution of the Cabinet of Ministers of Ukraine dated the 16th October, 2019 (there were changes to this Resolution dated the 30th of March, 2020 being the establishment of the transition of the Ministry and its tasks to the current format):

\footnotetext{
${ }^{13}$ Указ Президента України № 287/2015: Указ Президента України від 26 травня 2015 року. URL: https://zakon.rada.gov.ua/laws/show/287/2015\#n2 (дата звернення 17.04.2021)

14 Указ Президента України № 392/2020: Указ Президента України від 14 вересня 2020 року. URL: https://zakon.rada.gov.ua/laws/show/392/2020\#n7 (дата звернення 18.04.2021)
} 
1) Providing the creation and implementation of:

- the state policy in cultural and language spheres;

- the state policy in the spheres of information sovereignty (within the limits of competence to manage the integral property complex of the Ukrainian National Information Agency "Ukrinform"), information security of Ukraine;

- the state policy in the sphere of state foreign broadcasting;

- the state policy in the spheres of popularizing Ukraine in the world, strategic communications, especially the dissemination of socially important information in Ukraine and abroad;

2) providing the elaboration and implementation of state policy in the spheres of cinematography, the restoration and preservation of national memory, interethnic relations, religion and protection of the rights of national minorities, tourism and resorts (excluding the implementation of state supervision (control) in the field of tourism and resorts), arts, protection of cultural heritage, museum affairs, export, import and return of cultural values;

3 ) proving the elaboration and implementation of state policy in the spheres of television and radio broadcasting, information and publishing sphere;

4) participation in elaborating and implementing the state policy for temporarily occupied territories of Ukraine in Donetsk and Luhansk oblasts, the Autonomous Republic of Crimea and the city of Sevastopol and the population there in order to reintegrate them into a cultural and informational space of Ukraine"15.

However, the Ministry of Information Policy in accordance with the Resolution of the Cabinet of Ministers of Ukraine dated the 14th of January, 2015 had the following tasks:

1) "providing the elaboration and implementation of the state policy in the spheres of information sovereignty and information security of Ukraine, especially of the dissemination of socially important information in Ukraine and abroad;

1-1) providing the elaboration and implementation of the state policy in the sphere of state foreign broadcasting;

1-2) providing the development of state strategic communications in Ukraine;

15 Постанова Кабінету Міністрів «Деякі питання діяльності Міністерства культури та інформаційної політики»: Постанова Кабінету Міністрів від 16 жовтня 2019 року. URL: https://zakon.rada.gov.ua/laws/show/885-2019-п\#Tехt (дата звернення 17.04.2021) 
2) providing the implementation of media reforms of the dissemination of socially important information"16.

And it is possible to see the following tasks of the separate Ministry of Culture in accordance with the Resolution of the Cabinet of Ministers of Ukraine dated the 3rd of September, 2014: "1) providing the elaboration and implementation of state policy in the spheres of culture and arts, cultural heritage protection, museum affairs, export, import and return of cultural values, state language policy; 2) providing the elaboration and implementation of state policy in the field of cinematography, restoration and preservation of national memory, interethnic relations, religion and protection of the rights of national minorities" ${ }^{17}$.

So, the current tasks of one Ministry of Culture and Information Policy are similar to the previous tasks of the Ministries (the formulations of these tasks are similar, except for the 2 from the Resolution dated the 14th of January, 2015, that is not entrusted to the Ministry of Culture and Information Policy). There is also one important additional aspect, namely 4 tasks of the Resolution dated the 16th of October, 2019. By the way, they can affect the effectiveness of the solutions for these tasks in political realities, including 11 functions within the framework of the realization of changes to the strategic communications that were previously entrusted to the Ministry of Information Policy and the Ministry of Culture within the implementation of the "Doctrine of Information Security of Ukraine"18. The effectiveness of the solution for the tasks will possibly be affected if the workload of the Ministry of Culture and Information Policy is not taken into account and the effective distribution of the responsibilities among its representatives is not organized.

It is also necessary to take into account the weakness being the result of the decisions made by Zeleneskyy as President and the IX convening

16 Постанова Кабінету Міністрів «Питання діяльності Міністерства інформаційної політики України»: Постанова Кабінету Міністрів від 14 січня 2015 року. URL: https://zakon.rada.gov.ua/laws/show/2-2015-п\#Техt (дата звернення 17.04.2021)

17 Постанова Кабінету Міністрів «Про затвердження Положення про Міністерство культури України»: Постанова Кабінету Міністрів від від 3 вересня 2014 року. URL: https://zakon.rada.gov.ua/laws/show/495-2014-п\#Tехt (дата звернення 17.04.2021)

18 Указ Президента України № № 47/2017: Указ Президента України від 25 лютого 2017 року. URL: https://zakon.rada.gov.ua/laws/show/47/2017\#Text (дата звернення 15.04.2021) 
of the Verkhovna Rada. The weakness has affected the effectiveness of the implementation of such functions enshrined by the Ministry of Information Policy as: the elaboration of the strategic narrative and its implementation; the elaboration and implementation of the strategy of information, providing the process of freeing and reintegrating the temporarily occupied territories. This was especially noticeable during the period of the Ministry of Information Policy not existing at all, even in a united form (from August 29th, 2019 to March 30th, 2020. A part of its functions was entrusted not according to its purpose to the Ministry of Culture, Youth and Sports). And during that time a number of representatives of the new government expressed the positions that did not correspond to the strategy of information providing the process of freeing and reintegrating the temporarily occupied territories and the strategic narrative of Ukraine at whole and even undermined them. In particular, there were separate statements from Premier Minister Denys Shmygal $^{19}$, People's Deputies from the party "The Servant of the people" Iryna Vereshshkuk ${ }^{20}$ and David Arakhamia ${ }^{21}$, the advisor of the Secretary of NSDC of Reintegration and Recovery of Donbas Sergii Syvoho $^{22}$. Most of these statements of the representatives of the new government did not result in any consequences for their authors, they refused to have said them by using the standard form "you understood me incorrectly", "I didn't keep this in mind". However, these statements were perceived and clearly recorded by the Ukrainian society and its opponents, first of all, the Russian Federation as a weakness of these strategies and the narrative that is not corrected, because its initiators were not responsible for it. The situation was it excluding two cases of the authors of the most controversial of such statements, as marked Syvoho and Vytold Fokin, who made similar statements during the

${ }^{19}$ Хоч каністрами, хоч бутлями. Шмигаль втретє пояснив свою позицію про постачання води до Криму. URL: https://www.bbc.com/ukrainian/news-51765535 (дата звернення 18.04.2021)

${ }^{20}$ Курс в НАТО сумніву не піддаю, але на сьогодні Україна не має жодної можливості для вступу - Верещук. Радіо Свобода. URL: https://www.radiosvoboda.org/a/news-nato-vereshchuk-kurs/30181090.html (дата звернення 18.04.2021)

${ }^{21}$ Арахамія попросив вибачення за слова про постачання води до окупованого Криму. URL: https://www.radiosvoboda.org/a/news-arahamija-vybachyvsya-za-slovapro-vodu-v-krym/30431030.html (дата звернення 18.04.2021)

${ }^{22}$ Війна на сході - це вина України?: Сивохо потрапив у гучний скандал через заяву про Донбас. ВГолос. URL: https://vgolos.com.ua/news/vijna-na-shodi-tse-vynaukrayiny-syvoho-potrapyv-u-guchnyj-skandal-cherez-zayavu-pro-donbasvideo_1188616.html (дата звернення 18.04.2021) 
period of August-September of $2020^{23}$ from the position of the first deputy head of the Ukrainian delegation within the Three-partied contact group in Minsk. Both of them were removed from office. So, it will be absolutely necessary for the leader of the new people within the Ukrainian government Zeleneskyy to provide coordinated actions for these people in this sphere and the contraction of the responsibility for uncoordinated actions in this sphere, if the current Ukrainian president actually seeks to implement the information providing the strategic narrative of Ukraine at whole and, in particular, the strategy for freeing and reintegrating the temporarily occupied territories in an effective way further. On this basis, it is possible to claim that the other necessary changes of the strategic communications within the public administration of Ukraine in this direction are: providing the effective functioning of the system of the realization of the changes of the strategic communications within the public administration of Ukraine, with the functions distributed within it to new power institutions and new people taking office within it.

2. It is also necessary to emphasize the following aspect of the realization of changes to the strategic communications of Ukraine using the system of its subjects. For example, the Security Service of Ukraine (SSU), in accordance with the "Doctrine of Information Security of Ukraine" dated 2016, was entrusted with:

- monitoring the domestic and foreign media and the Internet by using special methods of identifying the threats of Ukraine's national security in the information sphere;

- counteraction against special information transactions aimed at undermining the Ukrainian constitutional system, sovereignty and territorial integrity, escalation of socio-political and socio-economic situations" $^{24}$.

However, is performing these duties traced back to the activity of the SSU during that time? The SSU announced a suspicion of state treason and violation of citizens' equality depending on their racial, national belonging, religious beliefs, disability and other signs to Anatoly Sharij, including the fact that he "assisted the governmental and non-

23 Чому Зеленський звільнив Фокіна: найодіозніші заяви політика. URL: https://thepage.ua/ua/news/chomu-zelenskij-zvilniv-fokina-najodioznishi-zayavipolitika (дата звернення 18.04.2021)

24 Указ Президента України № № 47/2017: Указ Президента України від 25 лютого 2017 року. URL: https://zakon.rada.gov.ua/laws/show/47/2017\#Техt (дата звернення 15.04.2021) 
governmental structures of the Russian Federation in carrying out special information operations against Ukraine" dated the 16th of February, $2021^{25}$. And Sharij was been announced to be wanted by the 25 th of February. Sharij is a popular YouTube-blogger, his channel now has 2.44 million followers. Sharij has been actively distributing materials dedicated to the political themes since May 13, 2013. And since 2019 he has been actively acting in the political life of Ukraine first of all from its own "Party of Sharija." The SSU has acknowledged that Sharij A. A. actions correspond to state treason and violation of citizens' equality dated 2014. It is acknowledged by SSU, because the video installation has accompanied that the suspicion to Sharij is also based on his information materials of 2014. So, what is the next question to ask then? What were the SBU doing from 2015 to 2020 within the realization of the "Doctrine of Information Security of Ukraine" (not mentioning from 2014 within direct duties of SSU) to contradict such an established violator of the information security of Ukraine as Sharij?

Perhaps, this was a sole mistake of only the SSU within the maintenance of the information security of Ukraine because SSU did not get the NSDC's assistance. NSDC that according to the "Doctrine of Information Security of Ukraine": "must coordinate the activities of executive authorities to provide national security in the information sphere"26. And the NSDC, for example, imposed sanctions in this direction on 2nd of February, 2021, which enacted the decree of the President of Ukraine No. 43/2021 of the same day. These are sanctions against Taras Kozak, the People's Deputy from the IX convening and against three TV channels in his possession: "112.Ukraine", "Newsone" and "ZIK", which actively used to broadcast pro-Russian political rhetoric. The official basis for imposing sanctions was finding Kozak involving into the schemes of coal delivery from the occupied territories that contribute to financing terrorism. However, the evidence of this involvement was found even in $2016^{27}$ and Kozak was the owner of the marked channels: "112.Ukraine" - since December 2018, of

25 СБУ та МВС оголосили Шарія в розшук. Суспільне. URL: https://suspilne.media/123389-iran-ignorue-zapiti-ukraini-sodo-rozsliduvannakatastrofi-litaka-mau-mzs/ (дата звернення 18.04.2021)

26 Указ Президента України № № 47/2017: Указ Президента України від 25 лютого 2017 року. URL: https://zakon.rada.gov.ua/laws/show/47/2017\#Text (дата звернення 15.04.2021)

27 Як Козак робив бізнес на вугіллі з окупованих територій: пояснення Центру протидії корупції. 24 канал. URL: https://novyny.24tv.ua/yak-kozak-robiv-biznesvugilli-okupovanih-teritoriy-rosiya-novini_n1532711 (дата звернення 18.04.2021) 
"Newsone" - since October 2018 and "ZIK" since June 2019 and up to them being banned. So, there is one more question remaining, namely: what was the NSDC doing on this aspect within providing the information security and the realization of changes of the strategic communications of Ukraine? Those are the facts of the delays within the realization of the changes of the strategic communications within the public administration of Ukraine by some of the subjects of its system even to 5 years independently of persons holding positions within it. Of course, such delays were possibly caused by other factors, but explaining these delays by referring to them is harmful to these subjects of the realization of improvements of the strategic communications of Ukraine. It is because such delays during hybrid war waged by the Russian Federation against us and its permanent steps within it are possible to cause destruction of such subjects and Ukraine at whole and all explanations will be useless in case it occurs. Conversely, it is rational for the subjects of the system of the changes realization of the strategic communications within the public administration of Ukraine, to Ukraine and to Ukrainians to try to use all the strength to eliminate any delays through outside factors on the way to the realization of the marked changes of Ukraine during the hybrid war. This is the reason for the extreme relevance of the necessity of the following changes of the strategic communications in Ukraine. These changes are the elimination of delays in the realization of the changes of the strategic communications within public the administration of Ukraine by its subjects, that is fraught with destruction to these subjects and Ukraine at whole in the conditions of the hybrid war against the Russian Federation.

\section{CONCLUSIONS}

So, it was found as result of this research that the necessity of the strategic communications within the public administration of Ukraine has increased since 2014. It has increased due to the hybrid war waged by the Russian Federation against Ukraine causing enormous risks for Ukraine and Ukrainians not only in the physical aspects, but also in the information and communication ones. And the strategic communications are the most effective form of communication for the state authorities among themselves and with the society to increase the effectiveness of the actions of the state in the information space, the organization of the public administration and the state's response to external threats. The relevance of the hybrid war threats and strategic communications has 
been proven by having analyzed a large number of researches conducted by different political experts in this sphere such as Magda Y., Puban Y., Shpyga P and Pelepejchenko L., of Ukrainian thematic editions, namely via analyzing the content of all-Ukrainian edition "Day", as well as legislative regulations of Ukrainian state's actions in this direction. It was established that the changes of the strategic communications within the public administration of Ukraine in the period of 2014-2019 as the Ukrainian state's response for these threats are mainly within the elaboration and implementation of the Decision of the National Security and Defense Council of Ukraine "On the Doctrine of Information Security of Ukraine" from $29^{\text {th }}$ of December, 2016 year. The first Ukrainian official outlining of the phenomenon of the strategic communications as "a coordinated and proper use of communicative capabilities of the state - public diplomacy, public relations, military ties, information and psychological operations, measures aimed at promoting the goals of the state." a coordination of public diplomacy across the interagency community that should always strive to support nation's fundamental values and national security objectives". However, it has been established that it is necessary for the many subjects of Ukrainian public administration, Ukraine and Ukrainians to establish further changes of strategic communications in Ukraine as a result of the analysis of Ukraine's public administration in 2019-2021. Concretely these changes are

1. The elaboration and implementation of "Strategy of information security of Ukraine" with the redistribution of functions in the system of subjects of implementation of strategic communications' changes in accordance with new institutions of public administration in Ukraine;

2. Providing the effective functioning of the system of the realization of the changes of the strategic communications within the public administration of Ukraine, with the functions distributed within it to new power institutions and new people taking office within it;

3 . The elimination of delays in the realization of the changes of the strategic communications within public the administration of Ukraine by its subjects, that is fraught with destruction to these subjects and Ukraine at whole in the conditions of the hybrid war against the Russian Federation.

\section{SUMMARY}

This material represents the author's research on the changes of the strategic communications within the public administration of Ukraine 
since 2014 and up to now. The research starts with analyzing the reason for the importance of the changes of the strategic communications within the public administration of Ukraine. Clarifying the reasons among the challenges for Ukraine caused with the hybrid war gives us a basis for further research. This clarification is conducted on the basis of the analysis of a large number of researches done by political experts and the legislative regulations of Ukrainian state's actions in this direction and the content-analysis of Ukrainian thematic publications in this sphere. And the first of these researches is the analysis of the implemented changes of the strategic communications within the public administration of Ukraine in the period from 2014 to 2019. The second of these researches is the justification of the necessity for the particular further changes of Ukraine in order to finally organize the communication within the public administration strategically and long-term efficiently for good of the subjects of this administration, other Ukrainians and Ukraine at whole.

\section{REFERENCES}

1. Арахамія попросив вибачення за слова про постачання води до окупованого Криму. URL: https://www.radiosvoboda.org/a/newsarahamija-vybachyvsya-za-slova-pro-vodu-v-krym/30431030.html (дата звернення 18.04.2021)

2. Війна на сході - це вина України?: Сивохо потрапив у гучний скандал через заяву про Донбас. ВГолос. URL: https://vgolos.com.ua/news/vijna-na-shodi-tse-vyna-ukrayinysyvoho-potrapyv-u-guchnyj-skandal-cherez-zayavu-pro-donbasvideo_1188616.html (дата звернення 18.04.2021)

3. Закон «Про інформацію»: Закон України від 2 жовтня 1992 року. URL: https://zakon.rada.gov.ua/laws/show/2657-12?find=1\&text= політика\#w1_2 (дата звернення 17.04.2021)

4. Закон «Про телекомунікації»: Закон України від 18 листопада 2003 року. URL: https://zakon.rada.gov.ua/laws/show/1280-15\#Text (дата звернення 17.04.2021)

5. Курс в НАТО сумніву не піддаю, але на сьогодні Україна не має жодної можливості для вступу - Верещук. Радіо Свобода. URL: https://www.radiosvoboda.org/a/news-nato-vereshchukkurs/30181090.html (дата звернення 18.04.2021)

6. Магда Є. В. Виклики гібридної війни інформаційний вимір. Наукові записки Інституту законодавства Верховної Ради України . 2014. № 5. C. 138-142 
7. Пелепейченко Л.М. Стратегічні комунікації силових структур України в сучасному соціальному контексті. Інформаційна безпека людини, суспільства, держави. 2017. № 1 (21). С. 34-41.

8. Постанова Кабінету Міністрів «Деякі питання діяльності Міністерства культури та інформаційної політики»: Постанова Кабінету Міністрів від 16 жовтня 2019 року. URL: https://zakon.rada.gov.ua/laws/show/885-2019-п\#Text (дата звернення 17.04.2021)

9. Постанова Кабінету Міністрів «Питання діяльності Міністерства інформаційної політики України»: Постанова Кабінету Міністрів від 14 січня 2015 року. URL: https://zakon.rada.gov.ua/ laws/show/2-2015-п\#Tехt (дата звернення 17.04.2021)

10. Постанова Кабінету Міністрів «Про затвердження Положення про Міністерство культури України»: Постанова Кабінету Міністрів від від 3 вересня 2014 року. URL: https://zakon.rada.gov.ua/laws/ show/495-2014-п\#Text (дата звернення 17.04.2021)

11.Рубан Ю. Г. Стратегія гуманітарної безпеки України у контексті гібридної війни. URL: http://www.historians.in.ua/index.php/ en/dyskusiya/1341-yurii-ruban-stratehiia-humanitarnoi-bezpeky-ukrainyu-konteksti-hibrydnoi-viiny (дата звернення 16.04.2021)

12.СБУ та MВС оголосили Шарія в розшук. Суспільне. URL: https://suspilne.media/123389-iran-ignorue-zapiti-ukraini-sodorozsliduvanna-katastrofi-litaka-mau-mzs/ (дата звернення 18.04.2021)

13. Указ Президента України № 287/2015: Указ Президента України від 26 травня 2015 року. URL: https://zakon.rada.gov.ua/ laws/show/287/2015\#n2 (дата звернення 17.04.2021)

14. Указ Президента України № 47/2017: Указ Президента України від 25 лютого 2017 року. URL: https://zakon.rada.gov.ua/ laws/show/47/2017\#Tеxt (дата звернення 15.04.2021)

15. Указ Президента України № 392/2020: Указ Президента України від 14 вересня 2020 року. URL: https://zakon.rada.gov.ua/ laws/show/392/2020\#n7 (дата звернення 18.04.2021)

16. Хоч каністрами, хоч бутлями. Шмигаль втретє пояснив свою позицію про постачання води до Криму. URL: https://www.bbc.com/ ukrainian/news-51765535 (дата звернення 18.04.2021)

17. Чому Зеленський звільнив Фокіна: найодіозніші заяви політика. URL: https://thepage.ua/ua/news/chomu-zelenskij-zvilnivfokina-najodioznishi-zayavi-politika (дата звернення 18.04.2021) 
18.Шпига П.С. Основні технології та закономірності інформаційної війни. Проблеми міжнародних відносин / Шпига П.С., Рудник Р.М. 2014. № 8. С. 326-339.

19.Як Козак робив бізнес на вугіллі з окупованих територій: пояснення Центру протидії корупції. 24 канал. URL: https://novyny.24tv.ua/yak-kozak-robiv-biznes-vugilli-okupovanihteritoriy-rosiya-novini_n1532711 (дата звернення 18.04.2021)

20.Definition of Aggression, United Nations General Assembly Resolution 3314 (XXIX). URL: http://hrlibrary.umn.edu/instree/ GAres3314.html (access date 16.04.2021)

21.US National Strategy for Public Diplomacy and Strategic Communication. URL: https://2001-2009.state.gov/documents/ organization/87427.pdf (access date 16.04.2021)

22. Vandiver J. SACEUR: Allies must prepare for Russia 'hybrid war'. URL: http://www.stripes.com/news/saceur-allies-must-prepare-forrussia-hybrid-war-1.301464 (access date 16.04.2021)

\section{Information about the authors: Borovskiy O. O.,} Candidate of Sociological Sciences, Associate Professor at the Department of Sociology Taras Shevchenko National University of Kyiv 60, Volodymyrska str., Kyiv, 01601, Ukraine

Tkachenko O. O., Master of Arts Students of Faculty of Sociology Taras Shevchenko National University of Kyiv 60, Volodymyrska str., Kyiv, 01601, Ukraine, President NGO "International Association for Political Science Students in Ukraine" 43, Lomonosova str., Kyiv, 03022, Ukraine 